\title{
INSTITUTIONAL INVESTMENT AND THE PROBLEM OF EQUITY FINANCING
}

\author{
HarRy G. Guthmann*
}

The general interest in the subject of this article results from the widespread belief that equity, or common stock, financing in this country is greatly handicapped by a lack of a suitable institutional supply of investment funds. The evidence for this belief is found in the agitation for the creation of special private and governmental agencies to do this job. It is also seen in the movement to permit regulated institutions and trustees to invest in common stocks even though investment considerations may have provided the primary motivation. The literature of finance offers further testimony on the point. ${ }^{1}$

The general lack of new private investment during the depressed I930's led some to underestimate the vitality of private enterprise. After the end of World War II in I945, however, the tempo of business continued at a high pace and ownership funds as well as creditor funds flowed in on a substantial scale. The statistics of bond flotations, bank loans, and mortgages sold give a widely used measure of the creditor funds obtained, but relatively few stocks were sold. Because so much of the new ownership investment consisted of retained earnings, the volume and importance of the inflow of equity funds was greatly underestimated by many commentators.

Not only did existing businesses expand their ownership investment during this period, but a host of new businesses sprang up. The figure of 3,382,600 business units in 1940 , after declining during the war years to 3,045,100 in 1943 , forged vigorously ahead to $3,976,400$ or almost four million in $1948 .^{2}$ As we shall see later, the troubles of some business units, often founded and operated by none too skillful persons, may explain some of the complaints of an inadequate supply of capital funds. Such businessmen find the rationalization of "inadequate capital" more comforting than "inefficient operation" or "bad financial planning."

* A.B. I9I7, Syracuse University; M.B.A. 192x, New York University; Ph.D. 1929, University of Chicago; C.P.A. 1920. Morrison Professor of Finance, Northwestern University. Author, THre AwnLysis of Financial Statements (3d ed. I942); co-author (with Herbert E. Dougnll), Corporate Financial Policy (2d ed. 1948); (With Ralph E. Badger), Investment Principles and Practices (4th ed. I95I). Contributor to Fundamentals of Investment Banking (Investment Bankers Ass'n of America, I949); Kenyon E. Poole (Ed.), Fiscal Policies and the American Economy (I951), and busincss and financial periodicals.

${ }^{2}$ Although any bibliography here is impossible, the range of ideas pro and con may be had from three significant articles: Anderson, Trends in the Supply of Equity Capital, 28 Harv. Bus. Rev. 79-89 (Sept. 1950); Bogen, The Importance of Equity Financing in the American Economy, 5 J. Finswce I70-I78. (June, 1950); Butler and Ulin, Business Needs for Venture Capital, 28 Harv. Bus. Rev. 52-65 (July, 1950).

2 Statistical Aestract of the United States, x950; Survey of Current Business, t949 Stattstichx Supplement (U. S. Dep't Commerce, May and June, r950). 
The economist is concerned with the adequacy of capital supply to provide the economically competent businessman sufficient means to produce the nation's goods and services rather than with the troubles of the individual business. For him the over-all evidence of extraordinary production during World War II and of an expanding national productivity since, of substantial growth in industrial capacity, and of expansion in the number of business units should raise some doubts as to the acuteness of the so-called "equity financing problem." This article will (I) analyze the investment problems of our leading financial institutions which explain the difficulties in the way of their helping with equity financing, (2) study how certain other institutional arrangements are increasingly meeting the problem, (3) analyze how business has raised equity capital as well as it has during the last decade, and (4) attempt throughout to discover any inadequacies of our institutional machinery, especially under the changing conditions of the last two decades. An understanding of these points is essential if the problems of equity financing are to be met wisely in shaping legislative and tax policies.

\section{I}

\section{Pertinent Investment Factors in Institutional Investment}

Perhaps the most important factor influencing the investment policy of our major financial institutions is the contractual arrangement under which they acquire their funds from the public. The great bulk of the funds is acquired by the major institutions by assuming a fixed dollar debt. These institutions are the banks, both commercial and savings; the savings and loan associations; and the life insurance companies. To remain solvent, they must keep a sufficient amount of fixed value assets on hand to cover these liabilities. The government through the regulatory process sets standards of solvency and often fixes the permissible kinds of investments. Both commercial and savings banks derive the bulk of their funds from depositors to whom they are obligated to repay a fixed amount of dollars either on demand or on short notice. This contract imposes not only a requirement of solvency but of liquidity as well, the latter varying with the type of institution and the character of its deposits.

Technically the funds of the savings and loan associations are supplied by shareholders rather than depositors (the depositor in the mutual savings bank occupies a somewhat similar legal position). While the distinction is important in the sharing of earnings, the shareholder in these associations is protected by regulation that requires that the association meet tests of solvency for the dollar amount of his investment including both the original sum and any accumulated dividend credits. His account is kept much like that of a bank depositor. The practice of allowing withdrawals that became widespread during the 1920's has made these associations very similar in operation to a bank. Under the law governing federally chartered associations, they are, however, not required to allow withdrawals in full even after due notice, but can limit them to a percentage of their net cash receipts. This 
privilege might seem to relax their need for liquidity even if not their solvency requirements. In practice, any association which hopes to remain in business must meet withdrawal requests with promptitude in order to command the confidence necessary to acquire and hold the funds of the community.

Life insurance companies, both stock and mutual, derive the great bulk of their assets from policyholders. In order to maintain a level premium over a lifetime during which the risk of death is rising, an excess premium is collected in the early years and set aside as a "reserve" to bear the burden of higher death losses in later years, which would otherwise cause a steadily rising premium. This "reserve" element in the premium is exactly computed on the basis of certain assumptions as to future mortality, interest earnings, and expenses, and after its collection is shown as a definite amount of liability to the policyholders. The company is bound to keep this amount of assets on hand or suffer the penalty of being declared insolvent by the regulatory authorities. Moreover, the company is obligated to pay, or loan, back substantially the full amount of this "reserve" under the cash surrender and loan provisions of most policy contracts.

A considerable point has been made of the lack of fluctuation of assets held by life insurance companies in spite of these provisions. Even in the two worst depression years, I932 and I933, cash receipts greatly exceeded cash outgo at least for the major companies. ${ }^{3}$ This point does have importance in reducing the need for liquidity of life insurance investments, but leaves unsolved the problem of solvency. For an institution with substantial fixed dollar liabilities, assets of fluctuating value pose a problem that must be met either by an adequate surplus of assets over debts or some standard of valuation that permits the regulatory authorities to ignore some part of the fluctuations that would otherwise spell insolvency.

Let us first consider the cushion for absorbing losses or fluctuations of the financial institutions mentioned thus far. The following table shows the comparative importance of the liabilities of each and their "surplus" for absorbing losses too great to be borne by current earnings. The safety margin in the case of the stock corporations, such as the commercial banks and some of the life insurance companies, consists of the capital stock, surplus, and surplus reserves. For the mutual institutions, such as the savings banks, savings and loan associations, and most of the life insurance business, there is no stock but only surplus and reserves built up by the retention of part of the earnings in good years.

The table shows a range of "surplus" over liabilities of between 5 and ro per cent, which represents an average of all the units in a given field. Individual concerns would deviate from these figures. If a concern with a ro per cent surplus invested ro per cent of its assets in fluctuating common stocks then a change of one percentage point in the value of such stocks would produce a corresponding percentage change in surplus. A decline of stock values of 50 per cent would dissipate half the surplus.

\footnotetext{
${ }^{3}$ Badger, Unusual Features of Life Insurance Investing, 6 J. Finswce 78 (June, I951).
} 
Surplus over Liabilities of Leading Financial Institutions

\begin{tabular}{|c|c|c|c|c|c|c|c|c|}
\hline & \multicolumn{8}{|c|}{ (Percentages) } \\
\hline & \multicolumn{2}{|c|}{$\begin{array}{l}\text { Life Insr. } \\
\text { Companies* }\end{array}$} & \multicolumn{2}{|c|}{$\begin{array}{l}\text { Mutual Savings } \\
\text { Banks } \dagger\end{array}$} & \multicolumn{2}{|c|}{$\begin{array}{l}\text { National } \\
\text { Banks† }\end{array}$} & \multicolumn{2}{|c|}{$\begin{array}{l}\text { Savings \& } \\
\text { Loan Assns. }\end{array}$} \\
\hline & 1940 & 1949 & 1940 & 1949 & 1940 & 1949 & 1940 & 1949 \\
\hline 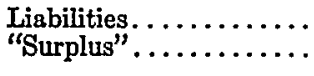 & $\begin{array}{r}94.1 \\
5.9\end{array}$ & $\begin{array}{r}93.0 \\
7.0\end{array}$ & $\begin{array}{l}89.2 \\
10.8\end{array}$ & $\begin{array}{r}90.1 \\
9.9\end{array}$ & $\begin{array}{r}90.6 \\
9.4\end{array}$ & $\begin{array}{r}93.2 \\
6.8\end{array}$ & $\begin{array}{r}91.4 \\
8.6\end{array}$ & $\begin{array}{r}92.2 \\
7.8\end{array}$ \\
\hline Totals........ & 100.0 & 100.0 & 100.0 & 100.0 & 100.0 & 100.0 & 100.0 & 100.0 \\
\hline Dollar Totals (billions).. & $\$ 30.8$ & $\$ 59.6$ & $\$ 12.0$ & $\$ 21.5$ & $\$ 36.9$ & $\$ 85.1$ & $\$ 5.7$ & $\$ 14.6$ \\
\hline
\end{tabular}

Sources: "Spectator LFF Insuranice Yearboor.

tANNosl Reports OF THE Couptroller of the Corrench.

fTRENDS iN THE SAYingS AND LoAN FIELD 5 (Home Ioan Bank Board, 1950).

Herein lies the danger of fluctuating assets to these financial institutions and the common tendency to restrict common stock investments by law even for life insurance companies to from 3 to ro per cent of assets. Actually the more fundamental relation is that of risk assets to the cushion of surplus rather than to the total assets. This idea is found in the limitation in the recently passed New York law permitting common stocks for life insurance companies to the lesser of 3 per cent of admitted assets or one-third of the surplus. Clearly some surplus is essential to absorb losses on even fixed value debt investments. ${ }^{4}$ It is possible that a life insurance company with a small "surplus" would feel that all of it was necessary to absorb such other losses and consequently steer clear of any common stock holdings.

In passing it may be noted that liquidity requirements as well as solvency standards may influence the feeling of need for a protective surplus of assets over liabilities. One savings bank executive stated that he believed savings banks required more of such "surplus" than life insurance companies because of the greater possibility of deposit withdrawals as compared with life insurance policy surrenders. This possibility meant a cushion was needed to absorb possible losses if debt investments should have to be sold at a time when withdrawals coincided with low market prices. Such price fluctuations can and do occur in the prices of high quality bonds, such as those of the United States Government, without reflecting any change in credit standing or risk of loss but only an adjustment to a higher level of interest rates. A savings bank might regard the risk of such adverse price fluctuation in a long-term bond at an inopportune time as small in relation to the greater yield such bonds have offered in recent years in comparison with short-term investments of greater price stability. Commercial banks, on the other hand, have shown a general policy of investing

\footnotetext{
'In this connection, the loss experience of Massachusetts savings banks during the I930's is significant. John V. Lintner, Mutual Savings Banks in the Savings and Mortgage Markets (I948). The investment losses of leading life insurance companies during a period of stress are reported in OperAting Results and Investanents of the Twenty-Six Largest Legal Reserve Life Insurance, Companies in THE UNTTED STstes, 1929-38 (submitted by the Securities and Exchange Commission to the Temporary National Economic Committee, I939).
} 
their demand deposits in either short-term loans or Governments of short maturity since the early I930's to assure holdings of suitable price stability.

Before turning to the possibilities of a solution to the problem of common stock investments by these financial institutions through some scheme of valuation that ignores or provides for some part of these market price fluctuations, the unusual position of the fire and casualty insurance companies should at least be mentioned. Although less important in terms of assets than the groups treated thus far, their investment practice underlines the customary emphasis upon market price for valuation and the need for an equity "cushion" by a financial institution that would hold common stocks. The accompanying table shows not only the more substantial "policy-holders' surplus" for these insurance companies than for the previously discussed financial institutions, but also their larger relative investment in stocks. Even the life insurance companies invested less than 3 per cent of assets in all stocks and less than I per cent in common stocks. The various kinds of fire and casualty companies held stocks of from 6 to 34 per cent of assets in $1949 .^{5}$

But after the present philosophy of our financial institutions has been understood, the question still arises: Could not at least the life insurance companies with their lesser need for liquidity invest more in common stocks and be reasonably allowed to adopt some different basis than market price for valuation purposes? ${ }^{3}$ Proposals

Balance Sheet Proportions of Fire and Casualty Insurance Companies: 1949

\begin{tabular}{|c|c|c|c|c|}
\hline & \multicolumn{2}{|c|}{ FIRE \& MARINE } & \multicolumn{2}{|c|}{ Casualtit } \\
\hline & Stock & Mutual & Stock & Mutual \\
\hline $\begin{array}{l}\text { Liabilities and Surplus } \\
\quad \text { Liabilities } . \ldots \ldots \ldots \ldots \ldots \ldots \ldots \ldots \ldots \ldots \ldots\end{array}$ & 55.9 & .54 .2 & 67.5 & 71.9 \\
\hline 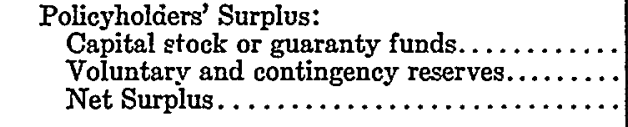 & $\begin{array}{r}8.4 \\
2.9 \\
32.8\end{array}$ & $\begin{array}{r}2.2 \\
4.4 \\
39.2\end{array}$ & $\begin{array}{r}6.8 \\
5.0 \\
20.7\end{array}$ & $\begin{array}{r}.8 \\
5.0 \\
22.3\end{array}$ \\
\hline Total "Surplus"..................... & 44.1 & 45.8 & 32.5 & 28.1 \\
\hline Liabilities and Surplus. $\ldots \ldots \ldots \ldots \ldots \ldots \ldots$ & 100.0 & 100.0 & 100.0 & 100.0 \\
\hline 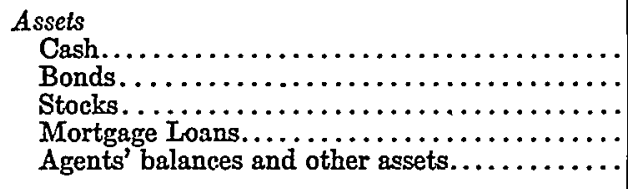 & $\begin{array}{r}9.4 \\
46.2 \\
35.9 \\
.4 \\
8.1\end{array}$ & $\begin{array}{r}10.5 \\
64.7 \\
15.2 \\
2.4 \\
7.2\end{array}$ & $\begin{array}{r}9.7 \\
59.5 \\
19.4 \\
.6 \\
10.8\end{array}$ & $\begin{array}{r}9.4 \\
75.3 \\
5.8 \\
1.6 \\
7.9\end{array}$ \\
\hline Total Assets. $\ldots \ldots \ldots \ldots \ldots \ldots \ldots \ldots \ldots \ldots$ & 100.0 & 100.0 & 100.0 & 100.0 \\
\hline Total Assets (millions).. & $\$ 5,563$ & $\$ 994$ & $\$ 4,112$ & $\$ 1,334$ \\
\hline
\end{tabular}

Source: SpEctator Instrance YgaB BOOEs, 1950.

'A fuller discussion of the investment policies of these and the other financial institutions may be found in R. E. Badger and H. G. Guthmann, Investament Principles and Practices (4th ed. 1951), Chapter 26, Investment Policy: Financial Institutions.

'A fuller treatment of this question is given by Fraine, The Valuation of Secarity Holdings of Life Insurance Companies, $6 \mathrm{~J}$. FinsNCE $124-\mathrm{I} 38$ (June, 195I), and the discussion of that paper by Harry L. Severson, id. at I39-I42. 
usually take the form of shifting from market value to cost with some plan for using extra yield and appreciation to set up reserves for possible losses and declines in market value. ${ }^{7}$ The supporting arguments are an analogy with the valuation of bonds by life insurance companies, an analysis of the economics of risk, and criticism of current market price as a measure of value for the purpose in hand.

Life insurance companies when purchasing bonds are expected to purchase only those of predominantly investment quality and these are shown initially in the accounts and the balance sheet at cost. Subsequently any premium or discount from par value is systematically written off (or amortized) over the life of the bond. The rate of yield becomes a constant rate of return on the changing book value and the balance sheet adopts this amortized value for measuring solvency. Market value changes are ignored so long as the bond does not default or lose its investment rating. 8

The essential thinking behind this treatment is that the cash needs of the life insurance company are such that they can be met by premium receipts, investment income, and repayments of principal from investments. The company should be able to hold its bond purchases more or less permanently or till maturity. Thus, a going concern standard of value rather than liquidation value as measured by market price is employed in accounting and measuring solvency. When bonds are purchased for long-term holding and with no intention of resale for the purpose of meeting withdrawals, it is believed logical to ignore market fluctuations that are not caused by a loss of credit standing sufficient to threaten the payment of interest and principal.

In this connection, it should be noted that solvency for a life insurance company requires not only that it own sufficient assets to cover "reserve" indebtedness, but that each year it must earn on this reserve the rate of interest assumed at the inception of the contract. Three decades ago that assumed rate guaranteed to the policyholder was ordinarily set at 3 or $3 \frac{1}{2}$ per cent. Today it is more often $2 \frac{1 / 2}{2}$ per cent, sometimes $2 \frac{1}{4}$ or 2 per cent. This stipulation for the life of the policy creates a special problem not found in either banks or savings and loan associations where the return may vary from year to year. Consequently, the life insurance company must not only solve the problem of having enough assets to cover debts at the end of each year, but must earn a minimum rate of return each year determined by its policy contracts. A return that included the gain or loss from market price changes would produce unhappily irregular results that would ignore the long-term obligation to earn a regular though low rate of compound interest. In this respect, studies which merely show a high average return could have been earned on a fund of com-

${ }^{7}$ On this point see Nerlove, Common Stocks as Investments for American Life Insurance Companies: A Non-Academic View, 3 J. Finance 39-5x (Oct. r948), and 4 id. 60-77 (Mar. r949).

- That even on the basis of market value bonds of quality fare well is indicated by a comparative study of Metropolitan Life and Sun Life in the early 1930's. The latter held 56.8 per cent of assets in stocks, chiefly common, in 1930 . The precipitous decline thereafter resulted in a change in policy so that in 1949 holdings of common had declined to 4.8 and preferred to 2.3 per cent of assets. Guthmann and Dauer, Stock vs. Bonds as Life Insurance Investments during Depression, 13 Harv. Bus. Rev. 237 (Jan. 1935). 
mon stocks over a period of years are inadequate. ${ }^{9}$ The showing year by year is required to cover this important point.

Unfortunately when we try to transfer the going concern value approach from bonds to common stocks, certain differences crop up. Common stocks have no fixed maturity value towards which market price is drawn so long as the debtor is solvent. Dividends are not a fixed return but fluctuate with business conditions and, for most stocks, to some extent with the price level. Before cost can be used in place of market value some assurance must exist that that figure will not result in a gross overvaluation when applied as a test of solvency.

One possible test of the validity of cost would be the current dividend return on that figure. So long as the dividends provided a rate of return on investment cost adequate to maintain the interest accrual required by policy contracts, it might be argued that the investment was adequate on a going concern base. Others might suggest that this minimum rate of return which would justify a cost valuation should be not less than the rate of return on the choicest of "riskless" bonds. The debate would also extend to whether the test should apply to the valuation of individual stocks or of the total of all stocks held. Custom would argue for testing the individual stock even though it might be argued that risk must be judged on group performance and that ability to continue as a going concern is a total asset problem.

Opponents of such an innovation would point out the dangers of "artificial" valuations in view of the demand liability nature of the cash surrender and loan provisions of the standard life insurance contracts. They would also point out how considerably dividends fluctuate with conditions so that the test might well give excessive valuations in good times that would encourage stock purchases at prices that would be fatally high in later depression years. Actually, under the proposed test of cost the investing life insurance company would need to ask the question at the time of purchase as to whether the stock being bought would be likely to pay a dividend equal to the stipulated rate of return on cost even during the most depressed years of business and in addition provide enough yield to cover the losses in this field of greater uncertainty and risk..$^{\mathbf{1 0}}$

\footnotetext{
${ }^{9}$ For example, see, for both annual and cumulative performance, A REPort in Support op Proposed Amendments to Article 5, Section 81, of the New York Insurance Law 68-95, 145-149 (submitted to the Joint Committee on Insurance Rates and Regulation of the State of New York by the Life Insurance Association of America and the American Life Convention, January, I95x).

${ }^{10}$ Nothing is said here of the possible use of a moving average of stock prices, say for the preceding three years, as a substitute for the customary year-end market price. Such an average price has no relation to the going concern value argument, which must be anchored to yield. While such a test would at times be less severe than a one-date price and give a more "representative" price, it would create new problems. It could give a very high "value" after a long boom and be so low after a prolonged depression as to prevent investment at what could be reasonable prices. Attempts at a "longterm value" measurement by some objective formula are likely to be illusory for the generality of common stocks. This difficulty is inherent in the fluctuating nature of income and the clement of futurity in the income to be measured. An objective measure is a prime necessity for any regulatory standard, which explains the common reliance on market prices.
} 
Clearly the least that is needed to justify common stock investment even under a new standard of valuation would be empirical studies that would indicate that stocks of the type deemed desirable would meet the income and solvency needs of life insurance companies year by year. Even though some excellent work has been done, studies are as yet unavailable that would cover both of these two points. Space does not permit a critical evaluation of the published research here. ${ }^{11}$ For the purposes of our discussion, however, two points should be mentioned. Most of the studies have studied group performance for combined dividends and appreciation over a period of years. This approach would give end results such as are obtained under a system of revaluation at market instead of cost. Very generally, however, information is lacking on one or more of the following points we have seen to be relevant under a system that used cost and had a problem of annual performance: (x) annual dividend performance relative to cost is lacking, (2) figures are not shown on an annual basis, or (3) the problem of maintaining annual solvency is not considered. It is insufficient for a life insurance company to earn a high average return. It must add the stipulated return to its reserve liability each and every year. High average return is also no substitute for continuous solvency by some standard of valuation, whether market, cost, or cost less some valuation reserve.

The results of some studies are greatly influenced by the particular years selected to begin and terminate the sample period. So large are the price fluctuations of most common stocks that one only needs to look at a chart of stock prices to judge how largely the factor of dates selected will influence end results that include price appreciation and depreciation.

One of the most interesting pieces of evidence favorable to long-term investment in common stocks has been the statistics of leading industrial common stock prices carried back to the beginning of the century. ${ }^{12}$ These figures show a remarkably regular long-term growth trend for the past half century at a rate slightly over $3 \frac{1}{2}$ per cent per year. Furthermore, the fluctuations about the trend have been contained for the most part within a band that runs somewhat over one-third of the value of the trend line on either side of it. An extraordinary rise above this band of price range occurred in the four bull market years of I927-I930. It fell below in the two years I932-I933 and again in the three years I940-1942. So impressive does Fraine find this record that he states: "Historically, the risk in common stocks as a class has been a short-time rather than a long-time risk, a risk of cyclical rather than secular depreciation."13

If such long-term regular growth could be reliably projected into the future for all common stocks, a far more satisfactory basis for investment would be laid than

\footnotetext{
${ }^{11}$ For a summary and brief discussion of such leading studies as those by Edgar L. Smith, Rose, Jackson, Rodkey, and others, see BADGer and Gutmanan, op. cit. supra note 5, at Chapter 6, The Return on Investment.

${ }^{12}$ A reproduction of Standard \& Poor's Long-Term Index of Industrial Stocks: 1900-1949, is given in Badger and Guthmann, op. cit. supra note 5, at 149 .

${ }^{13}$ Fraine, supra note 6 , at 128 .
} 
has yet been regarded as possible. Indeed, if such a basic trend could be relied upon, the likelihood of long-term price appreciation or depreciation could be estimated from the market level at the time of purchase with reference to this imputed trend. Or better still, investment policy might confine purchases to those periods in which the stock market was below the trend line. ${ }^{14}$ Consistent results would seem most likely for the large investor, such as an institution with sufficient funds to purchase a representative cross-section of the market represented by these averages.

However valid such a projection of the past into the future may prove to be, the basic problems of regular income and of valuation remain to be worked out or tested. There is, of course, the possible argument that cost or cost less some valuation reserve might be safely employed on the basis of these figures on the theory that at some future time any market depreciation will be offset by the automatic working of the growth factor.

Actually, three major factors may be mentioned which might interfere with the conclusion that this pattern of common stock prices is the probable pattern for the future of stocks generally:

(I) The growth trend described was based upon industrial rather than all common stocks. This point has special significance because of the differences in different fields of business. As late as the r920's, railroads were regarded as a growth industry and railroad common stocks enjoyed a better investment standing than industrials. Not until that decade were industrials regarded as suitable for other than speculative commitments. During the following decade only a very few railroads were able to maintain an unbroken dividend.

Electric and telephone utility operating company common stocks would be expected to offer less opportunity than industrials for growth in value but greater stability both as to income and value. ${ }^{15}$ Their business represents a low-priced consumers' service likely to enjoy stable demand. It is largely monopolistic. In the last two decades a fixed original cost-less-depreciation valuation has been increasingly adopted by regulatory commissions as the base upon which a fair rate of return should be allowed. Reproduction value has been increasingly ignored since Supreme Court decisions made that possible. ${ }^{16}$

Some regard bank stocks of better quality as more stable commitments than industrial common stocks because their assets consist of cash, loans, bonds, and mortgages-all fixed dollar value items (Massachusetts, for example, made bank stocks permissible investments for mutual savings banks in 1950). The high mortality among American banks in the past is believed unlikely of repetition because

\footnotetext{
${ }^{14}$ For an investment formula based upon this theory, see Lutcrle TomLinson, Successful INvestino Formulas (rev. ed. r950).

${ }^{15}$ The possibilities of investment in this field have been explored in BroN B. Howard, Public UTiLITY Common Stocks as Possible Investaments for Life Insurance Companies (unpublished doctoral thesis, Northwestern University, I950).

${ }^{16}$ Los Angeles Gas \& Electric Corporation v. Railroad Commission of California, 289 U. S. 287 (I933). Also Lindheimer v. Illinois Bell Telephone Co., 292 U. S. I5I (I934).
} 
of the panic preventive nature of federal deposit insurance and the more conservative investing and lending policies since the banking debacle of 1934 .

(2) The record of growth was made by a wide variety of industrial stocks of all qualities, which might not be representative of performance by such stocks as would qualify as investment media. While stocks that would be regarded as suitable for institutional investment might out-perform the averages in their growth in value, the opposite might be true. It is easy to forget that the well-regarded stocks of today may have been the speculations of yesteryear, particularly during their early life history when they made their greatest growth. Investment quality implies by definition seasoned issues with an established dividend record. It would seem likely that such established companies would grow at a slower rate than younger companies and might well show a declining rate of earnings on gross investment in later years.

(3) The growth record was made during a half century characterized for the most part by a rising trend of commodity prices, which trend might change in the future. During the fifty years, I900-I949, the wholesale commodity price index of the United States Bureau of Labor Statistics rose by 167 per cent, or at an average annual rate of 1.98 per cent. This influence would be expected to be very favorable to industrial corporations with their assets consisting chiefly of plant and equipment, natural resources, and inventories (in contrast utilities under the present regulatory practice and banks would have fixed dollar value assets). The rising price level could thus explain a substantial part of the industrial stock growth trend of the last five decades.

Political cynics regard an inflationary trend for the future as an almost inevitable result of present economic and fiscal policies of our American government. The unsettled world outlook creates additional inflationary pressures. Nevertheless, a change of trend in the price level should be recognized as possible. Some regard the postwar boom as merely deferring rather than eliminating the danger of a reactionary deflation. They point to the precedents of other inflations followed by deflation. A younger generation of businessmen and economists are prone to forget that the United States witnessed a declining trend in the commodity price level that lasted for a generation. It ran from the end of the War of the States in 1865 to 1896 or a period of three decades.

Most studies of common stocks have necessarily been confined to years since that period. It is even doubtful as to how useful any record of their performance under the very different economic and political conditions prior to Igoo would be for interpreting current conditions. Most economists would probably agree that a stable or declining price level would have reduced the price appreciation of industrial common stocks from what was seen between Ig0o and 1950 .

In this connection, it is important to point out that any class of stocks that is favored by rising commodity prices is correspondingly hazardous for life insurance 
company investment during -a period of deflation. Those who urge life insurance investment in common stocks as a "hedge against inflation" are wont to ignore the fact that insurance contracts are dollar contracts for debt that allow no adjustments for price level change. They are also silent as to what would happen to financial institutions of this type during a deflationary period.

Much of what has been said here about these studies of common stock investment performance is a warning as to their empirical nature. In any worth while discussion of this sort, we must go beyond such a general warning and come to grips with the specific considerations which may cause the probable future to differ from the experience of the past. The possible degree of difference between the two constitutes the measure of risk in acting upon experience and is a matter of judgment. It is true that the very successful institution of insurance is itself based upon the statistics of the past with adjustments from time to time to meet changing conditions. There is a danger that the relatively certain results obtained in that field will lead to the belief that a similar degree of certainty can be had in the field of equity investment. Such certainty seems unlikely. The most obvious, though not the only risk-witness the novel troubles of the railroads since 1930-is that of cyclical fluctuation. The records of the past show how irregular that influence has been in timing, duration, and intensity upon business volume, profits, and dividends. Its impact has varied greatly upon financial institutions within a given field even in the relatively predictable matter of debt investment. Equity investment presumably would produce more diverse results.

Two important results of these studies of risk and the increased interest in equity investment may be a more systematic provision for losses and more logical tax treatment of such allowances. ${ }^{17}$ The improvement should encompass investment in bonds and preferred stocks as well as in any common stocks. Almost every economic analysis of the subject of investment return has emphasized the extra rate of return from risk investments as constituting a "premium for risk." Yet it is difficult to find examples of financial institutions which have systematically set aside this excess return to provide for investment losses. But since such losses occur irregularly and chiefly in years of depression rather than year by year, it is most desirable that the "premiums for risk" be earmarked as such and not appear as so much additional current earnings. Most financial institutions appear to make no such specific provision based upon excess yields but instead make irregular "appropriations of surplus" or they set up capital gains as a "contingency reserve," or occasionally, as a "reserve for investment fluctuations." Only recently in the commercial banking field has the federal corporation income tax law permitted an allowance for possible future loan losses as a deductible expense in place of the actual experienced loss in the current year. The allowance is based upon long-term loss experience of the past, however, rather than excess yield or any analysis of the quality of existing loans.

${ }^{17}$ A central theme of Fraine, supra note 6. 
An analogous provision for bond and stock investments by financial institutions would have much to commend it, especially if the provision were related to the quality of the investment as reflected in the market's appraisal. Yield differences reflect the market's judgment of risk from time to time. ${ }^{18}$ Such allowance for loss may result in either inadequate or excessive provision. It makes a considerable difference to a financial institution whether such allowances are accepted practice. The income tax factor has been mentioned. So long as the provision is regarded as optional and treated as a form of "contingency reserve" rather than as necessary and a type of "valuation reserve" (such as the reserve for depreciation or for bad debts), it is thought of as a financial luxury-nice if you can afford it. Moreover, some institutions may wish to avoid what seems to be unusual accumulations of surplus. The point would be particularly important in a state like New York where life insurance companies are limited to a ro per cent surplus accumulation. High yield from risky investments whether dissipated as "dividends" to policyholders or paid as income taxes to the government will not be available to meet losses when they do occur in a depression.

The general tenor of our discussion thus far has been discouraging to the development of an important place for common stocks in the portfolios of the financial institutions discussed. Of the four institutions discussed, only for the life insurance companies has there been a strong advocacy for some equity investments. Even though only a limited place at most would appear logical, the size of their total assets makes any interest important. With present resources of more than $\sigma_{3}$ billion dollars, even a I per cent allocation to equities would amount to 630 million dollars.

When we turn to certain other institutional arrangements we find very different investment needs and a growing interest in common stocks. These include institutionally administered trusts, pension funds, and investment companies.

II

\section{Institutionally Administered Trusts}

A large and growing institutional channel through which funds flow into business is the trust fund administered by a commercial bank. These banks will be referred to here as trust companies even though the work is most often merely that of a department of a state or national bank rather than that rare institution, a pure trust company. Common stocks have been a much more popular holding for these funds than for any of the financial institutions discussed hitherto. Although these institutional trusts and the financial institutions are both thought of as "fiduciaries" in the popular mind, important differences exist in their requirements and invest-

\footnotetext{
${ }^{28}$ Not all "excess return" over that on such "riskless" investments as United States bonds represents premium for risk. Some part of a higher rate of return may be required for the expenses of initial investigation and subsequent supervision even in the case of investment quality bonds and preferred stocks. More of such expense is incurred where whole loans are acquired as "direct placements." Expenses are still larger as a per cent on investment for residential real estate mortgages than for bonds. Other yield differentials result from differences in maturity, tax status, and marketability.
} 
ment policy. The trustee has no substantial fixed dollar liabilities as a rule and so does not have the continuing solvency problem of the financial institution. Probably the greater part of the claims to trust funds are determined by the income earned or are shares in the principal at whatever value the latter may have. Exceptions exist to whatever extent specific dollar incomes are dedicated to particular beneficiaries or specified amounts are to be paid from corpus at a future time (pension funds are an exception which will be discussed separately at a later point).

Investment policy should consequently be oriented toward the needs of the beneficiaries rather than to meeting the twin problems of solvency and liquidity that dominate the thinking of the major financial institutions discussed thus far. These beneficiaries are typically individuals with a cost-of-living problem rather than a dollar liability problem. Common stocks which provide some adjustment of income to a changing price level are appropriate for this requirement. A rising tide of sentiment favorable to common stocks over the last three decades has resulted not only from recognition of their virtues as an inflation hedge but also from an expectation of extra gain in the form of price appreciation. This hope of appreciation is based upon the increased values which may result from retained earnings and expansion.

This increasing regard for common stocks as investment media has caused the modification of laws governing the investment of trust funds. Although legality of an investment for trustees is thought of as being determined by court decisions in those states which follow the "prudent man rule," such jurisdictions have hastened matters by legislation. In California, for example, trustees were specifically authorized to invest in common stocks in I943. Even New York, a notably conservative state in such matters, amended its laws in $195^{\circ}$ to permit trustees to purchase a total of common and preferred stocks that meet certain standards up to a maximum of 35 per cent of a fund. Previously, the trustee had been substantially restricted to the same investments as were legal for savings banks.

Trustees may and often are freed from these restrictions upon investment by the terms of the trust instrument. ${ }^{10}$ Such freedom of action is logical in the large trusts which are most likely to seek the professional administration of a trust company. Larger trusts are able to diversify and so are better fitted to bear the risks of equity investments. The trustee is more apt to favor common stocks when they have been included in the original fund set up by the creator. ${ }^{20}$

Over a decade ago Riddle called attention to the substantial portion of trust investments administered by national banks committed to common stocks. At that time (I937), 2,555 million dollars or 3r.4 per cent of the 8,r35 million dollars of their

\footnotetext{
${ }^{19}$ The Trust Investment Study Committee of the New York State Bankers Association found in a study in 1949 of 20,000 trusts in that state with an aggregate value of over $\$ 4$ billion that the proportion of trusts limited to legal investments was over about 20 per cent by value and not much over 30 per cent by number of accounts.

${ }^{20}$ This influence is discussed in Riddle, Trust Investments: Their Extent and Some Related Economic Problems, 5 Law \& Contemp. ProB. 339, 345-347 (x938).
} 
investment trust property was in stocks. This compared with 1,260 million dollars or 26.4 per cent of the 4,774 million dollars reported in I93. ${ }^{21}$ Data elsewhere in the same article indicate these were chiefly common stocks. By 1950 these trust funds held investments totalling 18,399 million dollars of which 4,215 million dollars, or 22.9 per cent were in stocks. ${ }^{22}$ Since state-chartered banks have banking assets equal to about three-fourths of those held by national banks, it would seem not improbable that they might hold trust funds in a roughly proportionate ratio. Such a ratio would mean trust investments for both types of commercial banks in excess of 30 billion dollars.

Another bit of evidence pointing towards the increasingly favorable attitude of conservative investors toward common stocks is found in the endowments of colleges and universities. While the figures are not strictly comparable for the two years, the accompanying table may safely be read as showing a most remarkable growth in common stock holdings from II.5 per cent in I93I to 30 per cent of the total in $1946 .^{23}$

Comparison of Proportions of University and College ENDOWMENT Fund INVESTMENTS: 1931, I946

(The mean of the percentages of each fund at book value)

\begin{tabular}{|c|c|c|}
\hline & 1931 & 1946 \\
\hline 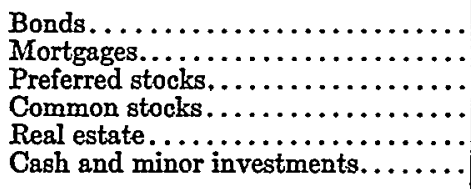 & $\begin{array}{c}50.5 \\
17 \\
8.5 \\
11.5 \\
9.5 \\
3\end{array}$ & $\begin{array}{c}42 \\
5.5 \\
11.5 \\
30 \\
8 \\
3\end{array}$ \\
\hline Totals. $\ldots \ldots \ldots \ldots \ldots \ldots \ldots$ & 100 & 100 \\
\hline
\end{tabular}

The trend has been slightly more marked for the institutions with larger endowment funds. As in the case of individual beneficiaries of trust funds, a university has a cost-of-living problem. Income is required to pay salaries and wages and buy supplies. These costs change with the general price level. Some income shrinkage can be borne with equanimity during deflation if counterbalanced by larger income during inflation. Moreover, since the endowment is substantially perpetual, market price fluctuations need not be a matter of concern.

Probably as important as any nicely reasoned argument that common stocks serve as an inflation hedge, has been the widened yield differential between common

21 Id. at 344 .

23 Annual Report of the Comptroller of the Currency (I950).

${ }^{23}$ The 1946 figures were compiled by Scudder, Stevens \& CLARK, SuRvey of UNIVERSITY AND College Endowment Funds I9 (I947); the I93I figures by WoOd, Struthers \& Co., Trusteeship of AMERICAN ENDOWMENTs (1932), but the latter figures are as adjusted and reported in the first source. For differences affecting comparison and variations in practice, see these sources. 
stocks and bonds since the early 1930's. ${ }^{24}$ Stock yields did not follow the declining trend of bond yields after I933. From a level around 5 per cent in the I920's, high grade bond yields declined to around 3 per cent by 1940. When it is realized that a 5 per cent return on invested endowment means two-thirds more income than a rate of 3 per cent, the pressure to shift to a heavier proportion of common stocks can be appreciated.

\section{III}

\section{Pension Funds}

A special type of trust which is likely to have a substantial bearing on the sums available for equity investment is the pension fund. These funds set aside by business corporations are designed to supplement the Old Age and Survivors Insurance of the Federal Government. Some corporate pension plans have been cared for by ordinary annuity policy contracts with life insurance companies but the more substantial part are based upon funds managed by trust companies. While satisfactory data are lacking, one estimate by an officer of a trust company holding substantial pension funds has placed the probable annual inflow of cash for pension trusts at $x 3 / 4$ billion dollars. A substantial part is expected to be invested in common stocks, possibly up to one-fourth of the total. ${ }^{25}$ Were such a figure approached, it would mean stock purchases of almost a half billion a year. So long as excess profit taxes are levied, corporations subject to that tax have a strong incentive to make extra contributions to build up reserves for pensions that have accrued from past services of employees prior to the setting up of the funds. A substantial part of these pension funds have been of postwar origin since I945, although the tax structure and wage restrictions of the war period provided a major impetus for the establishment of many.

These pension liabilities would seem to resemble the annuity liabilities of the life insurance company so closely that a similar fixed dollar investment policy might seem to be indicated. No attempt will be made to resolve the debate here but some of the chief arguments for a less restricted investment policy for pension trusts may be outlined.

(r) The liability for pensions is more uncertain because

a) it is affected by the uncertain factor of labor turnover. An employee who leaves the company before retirement may receive nothing except such amounts as he may have contributed himself. The employer's contributions remain to add support for the liability to the remaining employees.

b) the arrangement itself is characteristically a matter of union bargaining and may be changed from time to time.

c) benefits are typically a supplement to the federal Old Age and Survivors

\footnotetext{
24 For a graphic comparison of such yields from 1900 to 1949 , see BADGER AND GUTHMANN, op. cit. supra, note 5 , at 7 rg.

${ }^{25}$ Central Hanover Pension Bulletin, April, x950, pp. 2-3; id., July, 1951, pp. 3-4.
} 
Insurance which may change. When the scale of benefits for the latter was increased recently it reduced the liability of some corporations for pension benefits substantially.

(2) In any case the pension fund is typically inadequate at the outset to cover the accumulated liabilities for past services. Consequently any loss suffered through the price fluctuations, from a fraction (say up to one-third of portfolio) invested in common stock, is relatively unimportant. The longterm solvency of such pension funds must depend primarily upon the corporation's subsequent earnings and payroll being sufficient to permit adequate contributions. It is generally more correct to think of the pension fund as collateral to assist the business in carrying out its promises and to regard the pension liabilities as a corporate rather than a trust fund obligation.

(3) The absence of cash surrender values, save for the small amounts sometimes payable to employees who leave before retirement, means that security price fluctuations can be more readily ignored by a pension fund than a life insurance company.

Such arguments hinge upon a dependence upon the employing corporation's earnings and an underlying belief in the long-term merits of common stock investments and that they will yield more even after losses than an equivalent amount of fixed income investments. This expectation may go with a further belief in the efficacy of some formula plan that attempts to take advantage of the larger swings in the stock market. ${ }^{2 \theta}$ Nevertheless a company could suffer hardship if obliged to make up a deficit caused by declines in common stock prices or dividends at a time when its own earnings were depressed. After the employee has retired his pension is fixed in dollars.

\section{IV}

\section{INVESTMENT COMPANIES}

Investment companies offer one of the most hopeful institutional devices for channeling individual savings into equity investment. Basically they are investment pools through which the investor with a small sum can obtain diversification and management. They issue shares which have no fixed redemption value and so can invest freely in fluctuating values. Their holdings are predominantly common stocks. They give promise of developing into a major middleman between investors and equities in the way in which the savings banks and the savings and loan associations have stood between investors and bonds and mortgages.

Among their misfortunes was their founding and rapid rise to prominence in the speculative stock market boom in the late I920's. Their losses were accentuated by the heavy use of bonds and preferred stocks in their own capital structures so that the effects of the ensuing recession and deflation were multiplied. Many of their

\footnotetext{
20 See Tomminson, op. cit. supra, note r4.
} 
own shares shrank to a nominal value. Widespread disappointment and disillusionment threatened to crush this institution new to the American scene. However, one type of investment company, the mutual or open-end company, which avoided prior securities and issued only common shares, gradually increased in popular esteem and has enjoyed a rapid rate of growth since 1945. The rise in the stock market even brought a renewal of interest in the speculative issues of the closed-end companies whose stocks took on something of the character of a margin account because of the fixed claims of their bonds and preferred stock.

The mutual fund companies that gained the greatest popular favor invested chiefly in a diversified list of dividend-paying common stocks. Unlike the closed-end companies which offer their securities only irregularly in blocks like the ordinary business corporation, the mutual, open-end companies offer their shares for continous sale much like a savings and loan association. Similarly, they redeem their shares at any time, but not at a fixed dollar value. Repurchase price is based upon liquidation value, that is the market prices of their portfolio. The selling price, in turn, is based upon these market values plus a "loading" charge, averaging around $7^{1 / 2}$ per cent of the amount invested, to cover the sales commission and other distribution costs.

With high income and inheritance taxes reducing the savings of the wealthy as a source of capital, the relative importance of the investor of moderate income has grown. For the latter, a financial institution which assumes the cares of investment management and offers diversification to reduce risk is especially desirable. The success of financial institutions in directing the savings of the thrifty into debt investment is well known. The recent expansion of the investment company raises the hope of their similar success in the field of equities. Two factors have favored their recent growth. The first has been the relatively high dividend yields on market price, which, even after paying the costs of the investment company, have been substantially higher than the return offered by savings accounts in banks, savings and loan shares, life insurance, or even the favored Series E United States Savings bonds. The other factor has been the postwar inflation. Its effect in lost purchasing power has been that of a huge capital levy upon the thrifty who have invested in debt obligations. Losses have far exceeded the small rate of interest paid even before any deduction is made for personal income taxes. Common stocks, on the other hand, have provided rising dividend income and increasing market value to counterbalance this inflation at least in part during this period.

The following figures show the postwar growth of the open-end investment companies, which is the growing sector of this business. Their growth brought them up to the closed-end companies in 1950. While the absolute amounts are modestly small compared with the figures for the financial institutions investing in debt, the growth rate of the open-end companies has been higher. But once initiated into the nature of stocks, additional investment is likely to continue. The first sale 
Growth of Assets of Investment Companies (millions of dollars)

\begin{tabular}{|c|c|c|}
\hline Year & Open-end & Closed-end \\
\hline 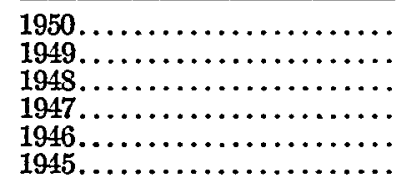 & $\begin{array}{l}2,445 \\
1,941 \\
1,524 \\
1,411 \\
1,297 \\
1,265\end{array}$ & $\begin{array}{l}2,463 \\
2,029 \\
1,728 \\
1,799 \\
1,931 \\
2,103\end{array}$ \\
\hline
\end{tabular}

Source: Secuntriza and ExcBange Coymagsion Statisticat Buthetins.

is the most difficult to make. Thereafter, the influence of continued personal salesmanship behind this institution should be an important expansive force. Because of the influence of market fluctuations the annual changes are a mixture of price change and additional shares.

\section{V}

\section{Is the Supply of Equity Funds Adequate?}

With the largest financial institutions devoted almost wholly to debt investment and only the trust funds, including pension funds, and the investment companies providing important institutional channels into common stocks, concern over the adequacy of investment in equities is easy to understand. Scanty information as to the amount and character of the investments of the funds administered by the trust companies has also caused their importance to be overlooked or underrated. The greatest impact of both pension funds and investment companies upon the capital markets almost certainly lies in the future.

Another argument used to show that the equity capital supply is inadequate has been the widened spread between the yields of bonds and stocks. Dividend yields have failed to follow the declining trend of high grade bond yields in the last two decades. Such evidence must be read with care. Dividend yields are not wholly comparable with bond yields. They relate the current dividend to current market price. Unlike the fixed return on a bond, the dividend may fluctuate and investors must look ahead in estimating probable long-run yield. Many investors in the postwar years have been constantly fearful of a waning of the boom. The higher level of commodity prices has also been suspect. Under such conditions the high current yield is regarded as temporary and market price, even though possibly mistaken, discounts the expected lower return. The current defense effort, similarly, is regarded by many as an extension of a temporary boom. Dividend yields might go lower as the result of either a decline in dividends as expected by such pessimistic investors or a change in investment temper that could cause prices to rise relative to dividends. Another possibility is that common stock yields may never decline so low as bond yields just as bond yields never decline to the lowest levels reached by short- 
term money rates. Space forbids a full-dress analysis but one reason would be that the perpetual maturity of common stocks gives them an inherently greater fluctuation of price range just as long-term bonds move more widely than short maturities. A given increase in yields above what the market has come to accept as "normal" means so much greater hazard of price reaction for common stocks than for debt investments of limited maturity. The increasing hazard of loss in market value as maturity lengthens should be one factor in preventing dividend yields from reaching as low levels as bond yields. In applying this principle to common stock price analysis, one must avoid too great reliance on published current dividend yields of particular stocks because in a given market the price may be discounting dividend expectations greatly different from the going dividend.

Still another argument that the supply of equity funds has been inadequate is found in the small amount of common stocks sold relative to bonds in the last few years. Comparative figures for the postwar years and the late 1920 's when equity funds were readily available are shown in the accompanying table. While these figures show greater relative sales of common stock in the Igzo's, the difference is not as substantial as one might imagine. They show a predominance of debt issues even during the stock market boom of $1926-\mathrm{x} 929$.

New Capital Issues of All Corporations and Retained Earnings

\begin{tabular}{|c|c|c|c|c|c|c|c|c|c|c|}
\hline & \multicolumn{10}{|c|}{ (Percentages) } \\
\hline & 1926 & 1927 & 1928 & 1929 & 1930 & 1946 & 1947 & 1948 & 1949 & 1050 \\
\hline \multirow[t]{2}{*}{$\begin{array}{l}\text { Common stock.......... } \\
\text { Preferred stock......... } \\
\text { Bonds and notes...... }\end{array}$} & $\begin{array}{l}12 \\
12 \\
76\end{array}$ & $\begin{array}{l}10 \\
17 \\
73\end{array}$ & $\begin{array}{l}21 \\
22 \\
57\end{array}$ & $\begin{array}{l}36 \\
24 \\
40\end{array}$ & $\begin{array}{r}21 \\
9 \\
70\end{array}$ & $\begin{array}{l}20 \\
21 \\
59\end{array}$ & $\begin{array}{l}13 \\
12 \\
75\end{array}$ & $\begin{array}{r}8 \\
7 \\
85\end{array}$ & $\begin{array}{r}12 \\
7 \\
81\end{array}$ & $\begin{array}{l}14 \\
13 \\
73\end{array}$ \\
\hline & \multicolumn{10}{|c|}{ (Billions of Doldars) } \\
\hline $\begin{array}{l}\text { Total new issues.... } \\
\text { Retained earnings.. }\end{array}$ & $\begin{array}{l}4.3 \\
2.3\end{array}$ & $\begin{array}{l}5.2 \\
1.1\end{array}$ & $\begin{array}{l}5.3 \\
2.5\end{array}$ & $\begin{array}{l}6.4 \\
2.3\end{array}$ & $\begin{array}{l}4.7 \\
4.3(\mathrm{~d})\end{array}$ & $\begin{array}{l}3.5 \\
7.6\end{array}$ & $\begin{array}{r}4.8 \\
11.6\end{array}$ & $\begin{array}{r}5.9 \\
12.8\end{array}$ & $\begin{array}{l}5.1 \\
8.6\end{array}$ & $\begin{array}{l}4.3 \\
12.5(p)\end{array}$ \\
\hline
\end{tabular}

(d)=deficit; $(p)=$ preliminary.

Sources: Capital issues-Commercial and Financial Chronicle. Figures exclude investment and holding companics. Retained

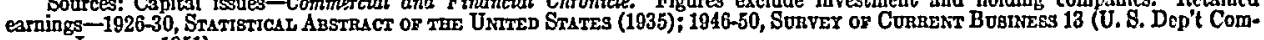
merce, January, 1051).

The chief weakness of such stock and bond data is that they ignore the most important source of equity capital, namely retained earnings. The amounts of such retained earnings have been added to the table where they can be compared with the amount of corporate capital issues. Inspection of the table is sufficient to show the overwhelming importance of the retained earnings during the postwar period as well as how considerably they increased in relative importance as compared with the late I920's. If they were added to the common stock issues sold the total common equity "financing" would have amounted to $7 x$ per cent in I 948 instead of the 8 per cent for stocks alone. Even in 1929 the combination of common stocks and retained earnings were but 53 per cent as compared with the 
$3^{6}$ per cent shown in the table for common stocks alone. The figures might be used to argue that such a relatively large use of retained earnings in the postwar years was itself evidence of the difficulty of the conventional common stock financing. It is also argued that the desire to avoid increased personal income taxes on dividends is a possible reason for retention instead of distribution. But with today's wide distribution of stock ownership by the large corporations which dominate over-all figures, management is probably less concerned on this point than for the smaller corporation owned by a limited group. The latter are much more apt to prefer reinvestment and appreciation over dividends. Management of major industrial corporations has probably been more influenced by the feeling that postwar earnings were in part an economic fiction. Earnings were increased by inventory price inflation and the effect of depreciation charges too small to replace the assets at the higher price level. ${ }^{27}$ Financing of such "expansion" by retained earnings rather than by new securities would seem desirable.

Various other lesser factors should enter into the interpretation of the statistics of capital issues as they relate to balance in corporate financing:

(I) New bond financing may understate the debt accretions because of bank borrowing not included. Other long-term debt than bonds may also be omitted.

(2) All debt is constantly being reduced by sinking funds and other payments. Common stocks are a source of substantially permanent funds.

(3) Bonds which are convertible into common stock appear among the debt issues but may be exchanged shortly after into common, thereby providing indirect equity financing. Such issues have been especially popular in utility circles since 1945 , whereas during the late I920's common stock was more commonly sold directly through rights. American Telephone and Telegraph Company has been a prime example selling 1,095 million dollars of convertible debentures 'during the five years 1946-1950. Conversions of these bonds during the same period reduced bonds and increased stock by $65^{\circ}$ million dollars and brought in 234 million dollars of paid-in surplus. Other prominent users of convertible bonds have been Detroit Edison and Consolidated Gas Electric Light and Power Company of Baltimore.

(4) Some writers also include depreciation funds as a source of equity money. To the extent that a business has enough income to cover all expenses including the allowances for depreciation and depletion, funds are available

${ }^{27}$ One estimate of the inflation influence on reported profits is as follows:

Corporation Profits

\begin{tabular}{|c|c|c|c|c|}
\hline ( billions of dollars) & 1947 & 1949 & 1948 & 1950 \\
\hline As reported................... 13.9 & I8.5 & 20.9 & 17.0 & $2 x .9$ \\
\hline As corrected $\ldots \ldots \ldots \ldots \ldots \ldots \ldots, 7.4$ & 10.7 & I6.x & 16.7 & I4.I \\
\hline Differences & 7.8 & 4.8 & 0.3 & 7.8 \\
\hline
\end{tabular}

Source: Machinery and Allied Products Institute, Chicago. 
either for replacement of the depreciated assets or for other general corporate purposes. The allowance itself is a bookkeeping writedown and not a cash outlay. When the resulting cash is not needed immediately for replacement it may pay for additional plant, equipment, or inventory that expands capacity. However, since such purchases are merely supposed to offset the losses in value of the depreciating assets, they are not included here. Their importance for financing either for replacement or new assets may be judged from their rise from 4.2 billion dollars in 1946 to 7.0 billion dollars in $1950 .^{28}$

Any attempt to decide how well balanced debt and equity financing have been must be based upon the net effect new financing, plowed-back earnings, debt retirement, conversions, and similar items have had upon the over-all financial condition of business. Probably no sector of business has viewed the equity market with more concern than the utilities. Their extraordinary expansion after I945 required equity money to keep capital structures in balance. Unlike most industrials, the utility finds retained earnings inadequate for growth partly because earnings are limited by regulation and partly because credit standing has required the substantial distribution of the bulk of earnings as dividends.

The balance of debt and equity interests in the capital structures of electric utilities is shown in the accompanying table.

\section{Capital Structure Proportions of Privately Owned Electric Utmlities} IN THE UNITED StATES: I939-I949

(in percentages)

\begin{tabular}{l|c|c|c|c|c|c|c|c|c|c|c}
\hline \hline & 1949 & 1948 & 1917 & 1946 & 1945 & 1944 & 1943 & 1942 & 1941 & 1940 & 1939 \\
\hline Long-term debt...... & 49.3 & 49.1 & 46.8 & 46.1 & 46.5 & 46.1 & 46.6 & 46.9 & 46.9 & 47.3 & 48.1 \\
Preferred stock...... & 13.8 & 13.9 & 15. & 15.2 & 15.7 & 15.5 & 15.1 & 14.8 & 14.4 & 14.2 & 14.2 \\
Common stock...... & 28. & 28. & 29. & 29.3 & 30.2 & 30.5 & 30.5 & 31.0 & 31.0 & 30.8 & 30.6 \\
Surplus.............. & $\mathbf{8 . 9}$ & $\mathbf{9 . 0}$ & $\mathbf{9 . 2}$ & $\mathbf{9 . 4}$ & $\mathbf{7 . 6}$ & $\mathbf{7 . 9}$ & $\mathbf{7 . 8}$ & $\mathbf{7 . 3}$ & $\mathbf{7 . 7}$ & $\mathbf{7 . 7}$ & $\mathbf{7 . 1}$ \\
\hline
\end{tabular}

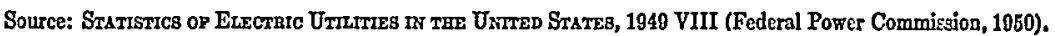

While the proportion of debt has grown from a low of 46.r per cent in 1946 to 49.3 per cent in 1949, that increase is in large part only a reversal of the decrease from 48.I per cent in 1939. During the war when construction was sharply restricted, debt could be retired with depreciation money. Such moderate changes can hardly be regarded as markedly affecting utility solvency.

Outside the utility field the characteristic reliance upon retained earnings for the bulk of equity money has left long-term debt within the capacity of business to pay. Increasing bank loans have also been moderate in relation to the growing working capital of business. Banks as a class have been inclined to caution after the experiences of the early I930's. The dominance of the institutional lender in the field of

${ }^{23}$ Survey of Corrent Business x3 $_{3}$ (U. S. Dep't Commerce, January, I95I). 
long-term debt financing has probably meant stricter standards than during the I920's when so much of the corporate debt was sold to individual investors. ${ }^{29}$

But the over-all figures of business are dominated by big corporations and the question might still be raised as to the availability of adequate equity funds for smaller concerns and for new ventures. Edrlier reference was made to the vitality of small business as reflected in the recent growth in the number of new concerns. The financing of these new concerns has been studied by the Department of Commerce. A sample survey of over a thousand new retail and wholesale trade firms during the period from I945 to I 947 was made. On this basis the report concluded: $:^{30}$

... of the estimated $\$ 7$ billion total of initial capital requirements by new trade firms during the $1945-7$ period, about $63 \%$ was financed by the personal savings of the entrepreneur, $\mathrm{x} 4 \%$ by bank loans, $8 \%$ by supplier credit and about $\mathrm{II} \%$ by other loans, mainly: from friends and relatives.

A small amount of the remaining 4 per cent was supplied by the capital markets, chiefly in the form of equity capital for new wholesale concerns. Of the approximately one billion of bank loans only about to per cent of the number and 4 per cent' of the value was represented by Veterans Administration guaranteed loans.

A similar survey of about 1,100 manufacturing firms newly established from 1946 to I948 showed a similar predominance of personal savings (60\%) as the șource of equity capital with other sources somewhat more important $(81 / 2 \%)$ than for trade. Bank loans ( $121 / 2 \%)$, trade credit (ro\%) and other loans ( $9 \%$ ) supplied the creditor funds. ${ }^{31}$

The importance of personal savings for new concerns is a natural outgrowth of a wide distribution of wealth and skills. Some ability to manage one's personal income so as to save is a desirable indication of possible ability to manage the affairs of a business thriftily. ${ }^{32}$ Creditors like to see a businessman able and willing to risk some capital of his own. Once business ability is demonstrated, credit that partakes of the nature of equity capital often follows. Such credit grows out of the

\footnotetext{
${ }^{20}$ In contrast, the Government through the continuance of F.H.A. guarantees into the boom years has encouraged 80 and 90 per cent loans. Such percentages are higher than those made during the 1920's by institutions which later experienced losses. The Reconstruction Finance Corporation, another Government agency, has made some notably higher percentage loans. States and municipalities are increasingly financing new ventures without any equity capital by the use of revenue bonds, i.e., bonds dependent upon net carnings rather than taxes.

${ }^{30}$ Lawrence Bridge, Capital Requirements of New Trade Firms, SuRvey OF Current Business 18 (U. S. Dep't Commerce, Dec. I948).

32 Bridge and Holmes, Capital Requirements of New Manufacturing Firms, Survey of 'CuRRENr Business II (U. S. Dep't Commerce, April, I950). Some further corroborative evidence of the ability of the small business to maintain its place in American business is found in statistics comparing the per cent of the national income by unincorporated and incorporated units annually from r929 to 1948 . The former would presumably be chiefly small and the latter large business. Because of the many factors affecting their interpretation, the data are only mentioned here. Surver of CurRent Business Io (U. S. Dep't Commerce, July, r949).

32 Roderick F. MCDonald, Adequacy of Supply of Capital for the Formation and Growth of SMall Business (unpublished doctoral thesis, Northwestern University, I95I) examines a number of new businesses, which illustrate the importance of personal qualities to survival and success as well as the variety of capital sources that are open to them.
} 
pressure to sell merchandise and to find profitable investment. Equity-like credits rather than actual equity investment fit the young business partly because of the jealous manner in which the owners seek to retain undiluted control and independence, and partly because those extending credit would find it time-consuming and unprofitable to spend the supervisory effort which would have to go with adequate control. Credits that are short-term may provide fairly permanent sources of capital so long as the business debtor gains their continuing renewal by meeting his obligations with reasonable promptness. Many devices exist for minimizing the need for equity capital, such as the rental of space for operations as well as the use of credit in the purchase of equipment, merchandise, and supplies.

Long-term credits and equity investment by outsiders are difficult to achieve for most small businesses on an economic basis because of their impermanence. This lack of permanence is associated with the dependence of such concerns upon one or two persons for continuance rather than upon a self-renewing organization with a large personnel. It also results from the rapidity with which a small working capital can be dissipated by operating losses and drawings of the owner. ${ }^{33}$ Equity capital for the small business is most logically supplied by the operator-owners or those closely associated with them. If success follows, the small business may grow rapidly from retained earnings and the credit which success commands. Retained profits for small business may be labor-return of the owner rather than the pure capital-return of the large corporation, which explains why the percentage growth may be startling. ${ }^{34}$ Successful owners often show a willingness to let their living expenditures lag behind their earning power.

The competitive system is directed to supplying goods and services that the community wants at the lowest costs. In so far as earnings are a satisfactory measure of economic want and low costs, a system that leans heavily on retained earnings for equity capital will favor the growth of the low-cost and efficient business units. Rather than forbidding or limiting entry to business, our economic system depends upon the forces of competition to regulate the major supply of equity funds (free entry is, of course, limited in certain fields, as in public utilities and banking).

The existing high birth rate of small business suggests that any increase brought about by making equity capital more available might add little to the population. It might only increase the death rate by an equal amount. The justification for stimulating the birth rate in an already well-populated business environment is doubtful. Perhaps the best argument can be made in the field of new manufacturing

\footnotetext{
ss This point is overlooked by the advocates of a system of government-guaranteed "equity-like" loans for small business that would parallel the F.H.A. guaranteed-mortgages loan system. The latter is secured by real estate of relatively permanent value; the small business loan rests upon an interest in assets which can shrink, be drained off, or become debt-encumbered with distressing speed.

se An interesting example of inverse correlation between size and growth rate is given in a list of 292 manufacturing corporations, whose financial statements became available after 1945 because of a sale of securities to the public. Sales expansion between I945 and I949 ranged from 94 per cent for corporations with sales under $\$ 2.5$ million to 20 per cent for those with sales of $\$ 20-25$ million. Monthly Letter on Economic Conditions (National City Bank of New York, Dec. 1950).
} 
ventures offering novel products or production methods or bringing industries to areas that seem fitted for economic production. Even here the search for business opportunities by existing concerns, by new enterprisers, and by communities seeking industry must be kept in mind. However, special institutions continue to be proposed and to be founded to aid in this job. The work of the recently founded American Research and Development Corporation, of the Industrial Development Bank (Canada), and the Industrial and Commercial Finance Corporation, Ltd. (Great Britain), of regional institutions fostered by commercial bankers and others, and legislative proposals such as the investment companies proposed in the LucasSpence bill are indicative of interested efforts to mend any gaps in this field of financing. ${ }^{35}$ However, the limited operations of institutions of this type as well as the experience of the Reconstruction Finance Corporation and Federal Reserve banks when given extended powers suggest but limited opportunities for new institutions.

In this connection the function of the stock market is often misunderstood and understated. Because new and small concerns cannot resort directly to the registered exchanges for money, they are regarded as playing no part in providing new venture capital. Actually a large part of the funds for any such venture is derived not from new current savings but from the liquidation of existing investment or speculative holdings. Liquidity is the essence of a good market for instruments of equity finance. Here is the cashier's window where old stocks may be cashed to buy new. Here, too, is the place for cashing in on successfully invested retained earnings. Not only is this true for the large corporation whose stock is already listed, but it is also true by indirection for the lesser, medium-sized business. Because of the stock market, the owners of the latter can sell all or a part of their holdings of a closely held venture once it has been built up to the requisite size. Or, they may merge it with a corporation whose stock is listed and sell the resulting shares. Marketability of stocks either present or prospective makes equity investment much more attractive. Such popularization of common stocks is especially important in a country that wishes a wide distribution of its wealth and uses inheritance and gift taxes that require partial liquidation of large estates.

\section{Conclusions}

The review of the problem of equity financing leads to the conclusion that American business has met its requirements remarkably well in spite of the lack of participation by major financial institutions and the increased burdens of taxation upon the conventional sources of equity money as found in corporate net income and personal incomes in the upper brackets. The commercial and savings banks, the savings and loan associations, and even the life insurance company do not appear well fitted to become equity investors in more than a minor way in view of their

\footnotetext{
${ }^{35}$ The problems and institutions in this area are more fully discussed by Schmidt, Meeting the LongTerm Capital Requirements of Small Business, 6 J. FinaNCE I43-I 49 (June, I95r).
} 
fixed dollar liabilities. A paucity of surplus over their indebtedness makes it hard for them to meet the solvency problem created by possible shrinkage of stock values. Such shrinkage may arise from ordinary business risks, cyclical fluctuations of business, or price level deflation. In this respect, some common stocks such as those of certain utilities may prove less vulnerable and more appropriate than others for limited investment. Two rising institutional channels give promise of directing more funds into equity channels. Both pension funds and investment companies draw savings from the low and moderate income groups. Their expected expansion is likely to be an increasingly important element in the stock market. Such a tapping of middle class savings is important in view of the generally held view that larger incomes and savings from such incomes have been hard hit by high federal taxes.

A continuance of the factors favorable to equity investment could result not only in an increased flow of current savings into common stocks but also a shifting of existing liquid savings from existing financial institutions. Higher yields and possible appreciation are potent stimuli where the individual is intent upon long-run accumulation as for retirement rather than desirous of liquidity to meet emergencies or short-term needs. Even life insurance companies might be affected by a greater demand for term and ordinary life at the expense of limited payment and endowment policies if accumulation through investment companies appears more attractive to more people. By providing more adequately for old-age retirement, pensions and federal Old Age insurance make term insurance more suitable as compared with policies that have a large investment element and require large reserves.

While the pension funds and investment companies are likely to concentrate upon the more seasoned stocks of major corporations, their buying will influence the whole market supply of equity funds. The stock market with its publicized prices and liquidity offers a constant means of comparison and an opportunity for easy shifting where bargains appear. Higher prices and lower yields for the more highly rated stocks will tend to raise the market value of less well rated issues. The more ample the supply of equity funds the more readily will funds become available for small as well as large enterprises.

Special institutions or measures for increasing the availability of either equity or credit funds have been tried and are frequently discussed. Useful though they may be, they have been relatively unimportant in directing funds into business channels save on special occasions as during the business depression of the I930's. Even then the valuable work of such governmental agencies as the Reconstruction Finance Corporation and the Home Owners' Loan Corporation was almost wholly to assume the investment burdens of other institutions temporarily rather than to meet new capital problems. During World War II, however, the R.F.C., the Defense "Plant Corporation, and the Smaller War Plants Corporation did yeoman service in aiding the war effort. 
The economic problem of equity capital, whether sought in the form of common stock or less obviously as marginal credit, will doubtless continue to receive considerable attention. However, the evidence of growth in equity capital, particularly as reflected in the record of retained earnings of established business and the formation of new business units in the postwar years, would strongly indicate that the problem is one which chiefly bothers the individual concern or a particular sector of business. The progress of the economy as a whole and its ability to balance debt increases with equity investment indicate that a shortage of equity capital has been no serious obstacle to business expansion and high productivity. 